\title{
POSSIBILITIES OF FOREST ALTITUDINAL VEGETATION ZONES MODELLING BY GEOINFORMATIC ANALYSIS
}

\author{
PETR VAHALÍK, TOMÁŠ MiKITA \\ Department of Geoinformation Technologies, Mendel University in Brno, Czech Republic, \\ Zemědělská1,61300 Brno,email:xvahalik@mendelu.cz,tomas.mikita.@mendelu.cz,
}

Received: $21^{\text {st }}$ February 2011, Accepted: $14^{\text {th }}$ June 2011

\begin{abstract}
According to Zlatnik (1976) there are 10 forest vegetation zones on the territory of the former Czechoslovakia. These are at present being modeled by phytocenological studies using bioindicator species of plants. Their incidence is affected by many abiotic factors, like temperature, precipitation or influence of climatic-inverse locations. By effective modelling of factors affecting the site requirements of bioindicator species, it is possible to make a comprehensive modelling of vegetation zonation. For the process of modelling, however, it is essential to identify the abiotic factors influencing this phenomenon and determine the extent of their influence. Hence, all the selected factors were analyzed using geoinformation tools and then combined with a typological map, which describes, among others, vegetation zonation in forest stands. The outcome of this combination was subjected to discrimination analysis, which identified influential factors and determined the extent of their influence. For modelling forest vegetation zones two methods were tested, first maximum likelihood clasification and second classification function of discriminant analysis in three territories with different reliefs. Both methods create a new raster of vegetation zonation based on geospatial relationship of individual factors and vegetation zones. Match of result models and input typological dates reaches $70 \%-90 \%$.
\end{abstract}

Key words: vegetation zonation, classification, climate, relief

\section{INTRODUCTION}

Forest vegetation zones and their modeling form a part of forest typology and in general represent an important background material for landscape, forest or environmental activities. The knowledge of their spatial distribution is also essential for biotope mapping, designing area systems of environmental stability and many other environmental works. According to Volařík (2010) vegetation zones as superstructure units are parts of two main typological systems used in the Czech Republic - in the system of geobiocenologic typology and in the forest typological system of the Forest Management Institute (ÚHÚL). In the former Czechoslovakia Zlatnik (1976) defined 10 forest vegetation zones, which bear the name of the dominant tree, in the potential natural state. They are 1. oak, 2. beech-oak, 3. oak-beech, 4. beech, 5, fir-beech, 6. spruce-fir-beech, 7. spruce, 8. dwarf pine, 9. alpine and 10. sub-nival. 
Forest vegetation zones show relationship between the sequence of differences of natural vegetation and the sequence of differences of altitude and exposure climate. Vegetation zonation is mainly dependent upon the temperatures of the air and soil and the amount and time distribution of atmospheric precipitation, incl. horizontal rainfalls. Shifts of vegetation zones are usually smooth, borders are diffuse, only some borders are sharp. Contacts and sequence of vegetation zones can be considerably modified by the specifics of mesoclimate. Inversion of vegetation zonation especially occurs in deep river cuttings influenced by climatic inversion (Buček, Lacina, 2007). Temperature and precipitation, therefore, have an important role in the spatial distribution of vegetation zonation. These climatic factors are mainly influenced by relief and elevation above the sea level. In terms of relief there are also other influential factors such as factors of exposition, slope or intensity of solar radiation and others. In general, it can be said that the influence of percipitation on landscape modifications is regional, given mainly by the morphology of the territory and its prevalent circulation of air masses, while temperature is of a local character. Solar radiation and average percipitation are directly connected with elevation above the sea level, as opposed to temperature. Intensity of the solar radiation increases together with rising elevation by $10 \%$ per one kilometer, while temperature decreases (by $0.54{ }^{\circ} \mathrm{C}$ per $100 \mathrm{~m}$ ) and the number of percipitation increases (Randuška et al., 2002).

The basis for modeling vegetation zonation at present is a phytocenological landscape study using the existence of bioindicator species of plants. Bioindicator species choose their sites based on their life requirements, which indirectly reveals abiotic factors influencing the spatial distribution of forest vegetation zonation. Through a summary and geospatial analysis of these factors it is possible to determine the extent of their influence on the phenomenon studied using the existing forest vegetation zonation maps which are the result of landscape typological mapping.

Forest vegetation zonation has been described in many geobiocenological studies together with factors influencing it (Zlatník, 1976; Buček, Lacina; 1999, 2007). Various authors describe a number of problems encountered when modelling vegetation zonation (Kusbach 2000, Grulich, Culek 2005, Grulich et al. 2005).

As mentioned above, the change in vegetation zonation is mainly influenced the by average temperature and percipitation in the given territory, which are determined by the combination of macroclimatic and mesoclimatic characteristics of the area. In terms of mesoclimate a greater influence is attributed to the configuration of the relief regarding the elevation of the territory and its geomorphology. In GIS all the characteristics of the relief are based on the digital models of landscape and ensuing geomorphological analyses. General geomorphological analyses necessary for effective mapping were a detailed subject of study of Klimánek (2006), Pike et al. (2008), Li, Zhu, Gold (2005), or Imhof (2007). Authors, such as Hadaš and Mikita (2008), described morphological-climatic analyses which influence the studied phenomenon, such as analysis of average temperatures with respect to altitude gradient or analysis of solar radiation. Very little research has been done in the area of climatic inversion and the related inversion of vegetation zonation in cut landscape formations with cold air accumulation and restricted circulation. How much the area is protected by the surrounding relief is often expressed by what is referred to as topographic exposure. Topographic exposure describes the degree to which an area is protected by the surrounding relief and in the given point it is equal to the sum of all the vertical angles to the horizon in eight basic cardinal directions (Ruel, 1995). Topografic exposure as one of the other important criteria for defining inversion areas in the relief with respect of its shape and prevalent direction of winds is studied in the following publications (Scott et Mitchell, 2005; Lanquaye et Mitchell, 2005; Ruel et Mitchell, 2002). The 
calculation of the topographic exposure is most often made using advanced analytical tools and scripts such as MPI - Morphometric Protection Index (Yokohama et al., 2002), which are part of the open source software SAGA (Software for Automated Scientific Analyses). Implementation of topographic exposure using the shaded relief in ArcGIS software is described by Mikita and Klimánek (2010).

Using geoinformation technologies for modelling vegetation zonation is a new approach which has not yet been described in detail in specialized literature in Central Europe. This topic was partly dealt with by Buček and Vlčková (2009) using the existing typological model describing the vegetation zonation in the Czech Republic for the prediction of the shift of these zones regarding the climate changes. Vegetation zonation using the digital elevation model was modeled by Volařík (2010) who defined vegetation tiers based on elevation, temperature and solar radiation.

The aim of this work is to analytically assess the extent of influence of individual factors which influence vegetation zonation with the objective to find suitable methods for modelling the studied phenomenon using advanced geoinformation analyses employing all available landscape, climatic or typological data.

\section{MATERIAL AND METHODS}

\section{Study areas}

Due to diversity in altitude and terrain in the Czech Republic, the study is applied on several locations with different relief features; therefore also weather, in order to represent different morphological and climatic entities. The study is based on the data of the following locations: training forest district of Krrtiny (cca 10,000 ha near the town of Adamov), south part of the Bílé Karpaty Mountains (cca 11,000 ha south of the town of Uherský Brod) and central part of the Moravskoslezské Beskydy Mountains (cca. 28'000 ha around Staré Hamry). These locations represent rolling hilly country with a lower precipitation amount and higher average temperature as well as mountainous location with high precipitation, low temperatures and a significant altitude variability.

\section{Table 1: Chosen characteristics of study areas}

\begin{tabular}{|c|c|c|c|c|}
\hline Study area & $\begin{array}{c}\text { Substitution of veg. } \\
\text { zones }\end{array}$ & Altitudinal range & $\begin{array}{c}\text { Temperature } \\
\text { range }\end{array}$ & $\begin{array}{c}\text { Precipitation } \\
\text { range }\end{array}$ \\
\hline Beskydy & $2 .-8$. & $368-1,324 \mathrm{~m}$ & $2.5-7.5^{\circ} \mathrm{C}$ & $946-1,532 \mathrm{~mm}$ \\
\hline Bílé Karpaty & $1 .-5$. & $264-968 \mathrm{~m}$ & $6.8-9.5^{\circ} \mathrm{C}$ & $538-920 \mathrm{~mm}$ \\
\hline Křtiny & $1 .-5$. & $212-573 \mathrm{~m}$ & $6.0-8.8^{\circ} \mathrm{C}$ & $509-707 \mathrm{~mm}$ \\
\hline
\end{tabular}

\section{Input data}

Factors describing characteristics of relief are based on hypsometry and planimetry originating from the ZABAGED (basic base of gegraphic data). Rasters of climatic factors are produced over the data (temperature, precipitation) measured by Czech hydrometeorological institute in years 1961 - 1990. Geology and soil conditions data are managed by Czech Geological Survey. 


\section{Data processing and analysis}

Processing spatial data was carried out in ESRI ArcGIS 10 software with the use of extensions Spatial Analyst and 3D Analyst. The base for the analysis was vector layer of forest typology for the chosen areas taken form the Local Forest Development Plan database (OPRL). Information source about the relief of the area were contour lines of the Basic Geographical Data Database (ZABAGED) further processed into digital terrain models (DTM) by means of a tool called TOPO TO RASTER. This tool creates hydrologically correct model and from the available interpolation tools it reaches the best results (Klimánek, 2007). The created DTM became basis for the creation of factors for further analysis. The analysed factors include the following: average annual temperature, annual precipitation, orientation to cardinal points, slope gradient, relief curvature, overall global annual radiation, topographical exposure factor, geonomy and geology of the area and a layer of distance from drainage system. All factors were in the ArcGIS software environment processed to rasters with spatial resolution of 5 metres.

Air temperature has a significant impact on the vegetation zonation. The temperature mostly fluctuates in relation with the changing altitude of the area. Also local zonation given by the shape of relief has a significant impact on the temperature changes. At the creation of the map of average temperatures, the Czech Hydrometeorological Institute climatic data from the nearest climatic stations were used. Regression analysis was used to statistically analyse the average annual values and thus was found out the equation of the dependence of temperature on altitude in areas of interest. (equation No.1 to 3)

T-avg $=9.8789-0.0061 * D T M$

equat. No.1. Dependence of temperature on altitude for the training forest district in Křtiny

\section{T-avg $=9.5059-0.0051 * D T M$}

equat. No.2. Dependence of temperature on altitude for the area of the central Beskydy Mountains

\section{T-avg $=10.245-0.0059 * D T M$}

equat. No.3. Dependence of temperature on altitude for the area of the Bile Karpaty Mountains

By calculating equations in the ArcGIS software, maps of average temperatures based on altitude were created; these however, do not make provision for the zonation of temperatures. This zonation was further solved by the calculation of temperature normality for chosen stations based on the equation:

equat. No. 4 ... T-norm $=\mathbf{T}$-real $/ \mathbf{T}$-avg,

where $\mathrm{T}$ - norm means temperature normality, $\mathrm{T}$-avg is the average temperature found out for the station according to regression equation, and T-real is average temperature measured by climatic station. The resultant value of normality is around 1, when lower temperatures mean stations below average and conversely higher normality suggests higher temperatures on average. By the interpolation of temperature normality values by means of the SPLINE tool, the values of normality for all areas under observation were calculated. From equation No. 4 it follows: 


\section{equat. No. $5 \ldots \mathbf{T}=\mathbf{T}$-norm $\mathbf{x} \mathbf{T}$-avg,}

this is why the map of average temperatures according to regression equation was further multiplied by temperature normality creating resultant map of average temperatures, which takes into account both the impact of altitude and the zonation of average temperatures.

In the case of average annual precipitation a similar procedure was tested, the results of regression, however, did not completely confirm the dependence on altitude, because in the case of precipitation the mentioned zonation plays a more important part. For example in mountain valleys there does not occur a significant decrease in precipitation as opposed to the surrounding hilltops. The map of average precipitation was thus created by a mere interpolation of values of precipitation-gauge station by means of SPLINE tool.

Regarding the changes of vegetation zonation a significant role is played by the factor of global radiation, which is given by the mutual combination of slope, exposition and relief curvature. The calculation of annual global radiation (direct and diffuse) was carried out directly in the ArcGIS software by means of tool Area Solar Radiation from DTM of areas of interest. The created maps express overall amount of solar radiation falling on the surface of the earth in $\mathrm{WH} / \mathrm{m} 2$.

The impact of climatic inversion was expressed as a factor of topographic exposure. The raster of topographic exposure was created by analytic illumination of the relief from 32 horizontal directions with the simulation of the current of air under the vertical angle of $5^{\circ}$ 32 - by the multiple use of the HILLSHADE tool (Mikita, Klimánek, 2010).

The factors of slope, exposure, and relief curvature were created by means of ordinary tools (SLOPE, ASPECT, CURVATURE) of the operating system add-on 3D Analyst of the ArcGIS software. The examination of the impacts also additionally included factors of soil composition and geological subsurface (Czech Geological Service data) gained by the conversion of vector maps and further also the factor of the distance from drainage system calculated by tool EUCLIDEAN DISTANCE from the vector layer of water course from ZABAGED.

\section{Evaluation of the ration of impact of individual factors}

All factors in the shape of rasters were combined by means of ArcGIS software with the raster of vegetation zonation from a typological map from the Local Forest Development Plan database (only forest areas). The resultant matrix of values for each pixel of the raster was exported as a table for processing into the STATISTICA 9 software and further analysed by discriminant analysis. Discriminant analysis is one of the methods of multivariate statistical analysis, which serves for discrimination of objects (pixels) coming from a final amount of classes (values of abiotic factors) to individual classes (vegetation zones). This is based on the knowledge of differences between classes and affiliation to given classes to groups from a training set (vegetation zones from Local Forest Development Plan data). The discriminant analysis applies the value of Wilks' lambda which determines the power of individual classes to correctly classify objects into desired groups. After defining fixed (vegetation zones from the training set) and moving variables (values of factors), a table of variables, which stand as candidates for the model, is calculated. Where the value of Wilks' lambda decreases, its power to classify correctly increases. (Kubíková and coll., 2010). In the next step a table of results of discriminant analysis is created where the Wilks' lambda value increases with increasing unsubstitutablity of a class in the model for the correct classification (see Fig. No.1). The height of this value identifies the unsubstitutablity of individual factors at correct assigning 
individual pixels into vegetation zones, which describes the ratio of influence of individual abiotic factors on the phenomenon under observation.

Fig. 1: The ratio of influence of abiotical factors on altitudinal vegetation zones

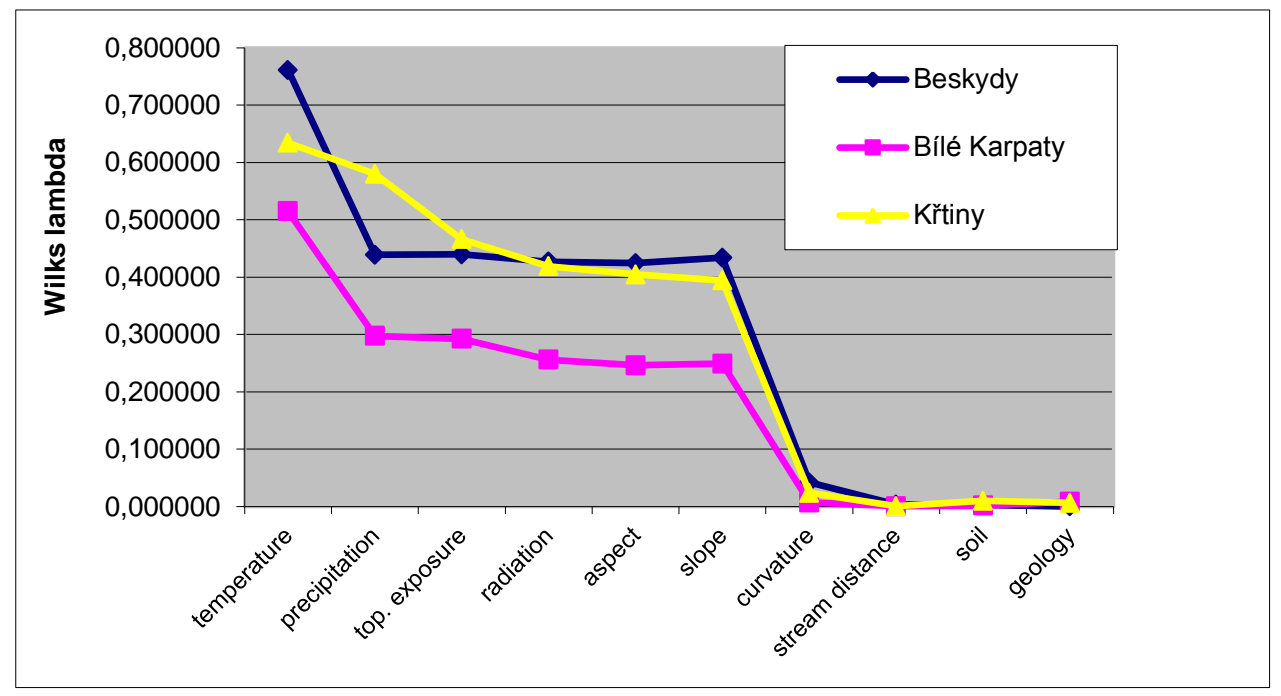

\section{Modelling of vegetation zones}

After the identification of significant abiotic factors all other factors with insignificant impact were eliminated from the model. The actual process of modelling vegetation zonation was done in two ways: by classification - by means of tool MLC (maximum likelihood classification) of the of the ArcGIS 10 software and by classification function of discriminant analysis of Statistica 9 software with subsequent use of the map algebra of the ArcGIS software.

MLC classification is a process of object oriented classification which based on covariation subdivides pixels into pre-set number of classes which corresponds to the number of entrance categories in a training set (that is vegetation zones). For determining covariation of individual pixels a signature set of the ASCII (American Standard Code for Information Interchange) type is used. The first step is the creation of signatures by means of tool CREATE SIGNATURES which creates ASCII file containing two types of information. One is the general information about all classes such as the number of elements, names of input rasters, class numbers and others. Second piece of information in the file are statistics of each class which comprise of numbers of features and their values of covariation towards the value from the training group (that is the value of the vegetation zone from the OPRL data). The set of signatures is thus used for the actual classification function which based on the comparison of values of covariation for each pixel calculates the value of likelihood, based on which it is assigned to a category of a vegetation zone.

Within the MLC tool it is also possible to define variants EQUAL and SAMPLE. In the first case, the pixels are assigned into individual categories only based on likelihood of their affiliation regardless of their original representation in categories of training sets. The SAMPLE variant at the choice of the category of destination takes into account the original 
representation of pixels in the categories of training sets. Having tested both possibilities the variant SAMPLE was chosen as the more effective one.

Classification function is based on the above described discriminant analysis used for the evaluation of the ratio of impact of individual factors. The calculation of Wilk's lambda defining significance of individual classes in the model is followed by the calculation of classification function. The classification function is a table where each class (factors) has its unique row and each category (vegetation zones) has its column. The values in the table represent variables with the help of which it is possible to calculate the value of likelihood of the affiliation of pixels to a vegetation zone, which is represented by a concrete column (see equat . No. 6 and Tab. No.2).

Table. 2: Table of the classification function of discriminant analysis (Bílé Karpaty)

\begin{tabular}{|r|c|c|c|c|c|}
\hline Factor & $\begin{array}{c}\text { Variables of } \\
1^{\text {th }} \text { veg.zone }\end{array}$ & $\begin{array}{c}\text { Variables of } \\
2^{\text {th }} \text { veg.zone }\end{array}$ & $\begin{array}{c}\text { Variables of } \\
3^{\text {th }} \text { veg.zone }\end{array}$ & $\begin{array}{c}\text { Variables of } \\
4^{\text {th }} \text { veg.zone }\end{array}$ & $\begin{array}{c}\text { Variables of } \\
5^{\text {th }} \text { veg.zone }\end{array}$ \\
\hline Temperature & 0.6092 & 0.6234 & 0.5883 & 0.5438 & 0.4798 \\
\hline Precipitation & 1.3303 & 1.3188 & 1.3374 & 1.2909 & 1.2404 \\
\hline Topex & 1.5563 & 1.6039 & 1.3346 & 1.2274 & 1.2932 \\
\hline Radiation & 0.000203 & 0.000201 & 0.000195 & 0.000188 & 0.000179 \\
\hline Slope & 5.3806 & 5.3118 & 5.1867 & 5.1501 & 5.0766 \\
\hline Aspect & 0.0353 & 0.0379 & 0.0355 & 0.0331 & 0.0318 \\
\hline Constant & -971.996 & -965.729 & -942.898 & -846.833 & -778.492 \\
\hline
\end{tabular}

equat . No. 6. Calculation of likelihood from the table of classification function

$\mathrm{F}_{(1)}=0.60922 *$ temperature $+1.33026 *$ precipitation $+1.55633 *$ topex $+\ldots-971.996$

$\mathrm{F}_{(1)} \ldots$ likelihood of pixel affiliation to the $1^{\text {st }}$ vegetation zone

This equation is subsequently processed by a map algebra in the ArcGIS 10 software tool RASTER CALCULATOR into the raster of likelihood for each category, that is the vegetation zone contained in the model. Each input raster thus carries the value of pixel corresponding to the likelihood of affiliation of a given pixel towards a given vegetation zone. Thus the same amount of likelihood rasters is created as is the vegetation zones in the model. These rasters are combined into one and analytically re-evaluated in a way that in each pixel a value of vegetation zone is assigned for which it has the highest value of likelihood affiliation. At some pixels, however, a concordance of likelihood occurs regarding values of affiliation to three vegetation zones, these pixels are removed from the raster (on average this concerns about $3 \%$ pixels in the model). At the concordance of two likelihood values the pixels are marked as transitions between two neighbouring zones (on average $18 \%$ pixels in the model) and are marked as double-digits in relation to the value of vegetation zones whose transition they represent. 
Fig. 2: Training forest district of Křtiny from OPRL data

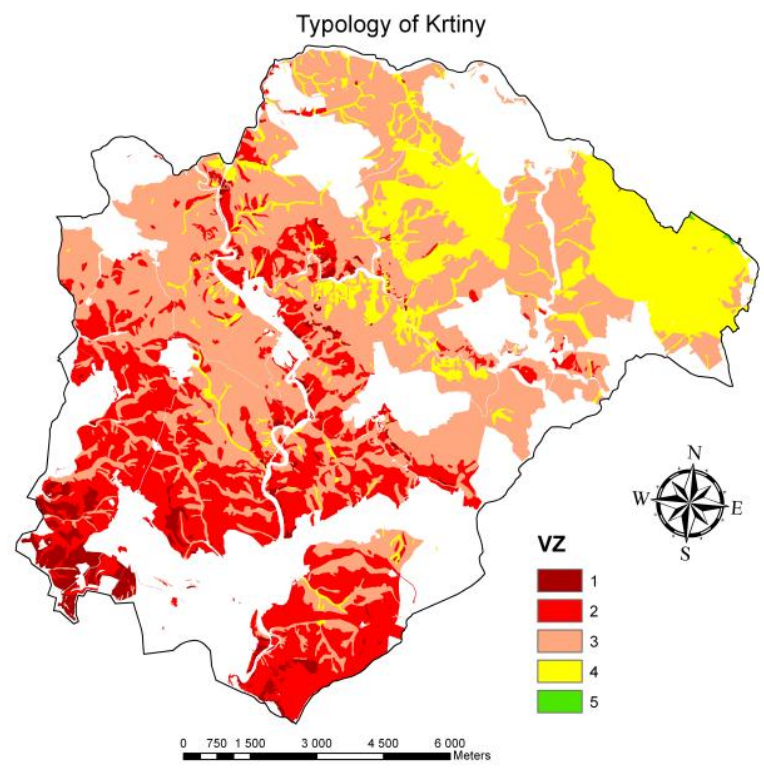

Fig. 3. Training forest district modelled by non-linear classification function (doubledigit values signifying pixels with uncertain classification to neighbouring vegetation zones.

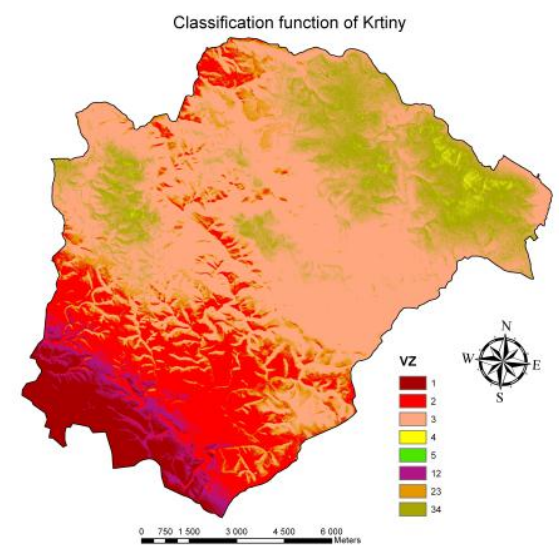

Fig. 4. Training forest district of Křtiny modelled by MLC analysis

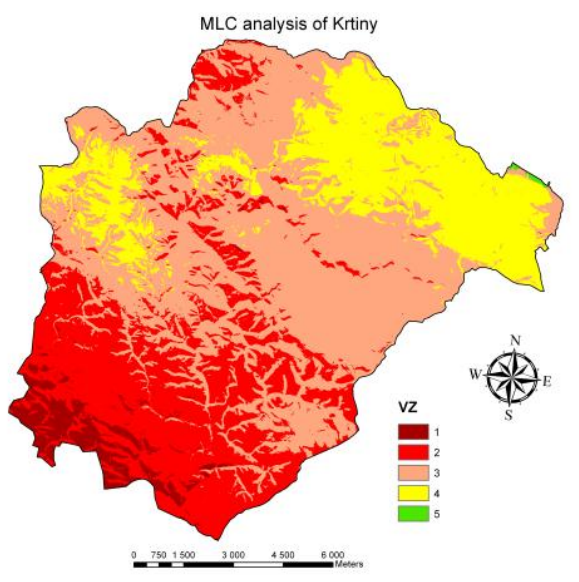


Spatial distribution of analyzed factors for researched phenomenon modelling shows a high rate of spatial non-linearity (increasing precipitation against lowering temperature according to elevation etc.), that's why the model has also been tested by non-linear geostatistical tools and by several types of artificial neural networks, i.e. multi-layer perceptron network (MLP), radial network (RBF) and Kohen network, which are incorporated in the Idrisi Taiga software. However, results of these non-linear statistical methods couldn't provide an explicit classification of individual pixels into respective vegetation zones, even in spite of employing a variable number of hidden layers (classification function neuron layers) and change of BIAS parametre (boundary value for exiting a training phase and activating the network). Resulting models identically classified whole area in two or three classes representing the most widespread vegetation zones. MLC tools and classification functions prove to be by far more effective in this respect.

\section{RESULTS}

According to discriminant analysis the most influental factors affecting spatial distribution of vegetation zones are temperature, precipitation, topographic exposure, solar radiation, exposition and slopes with Wilk's lambda value over 0.1 (see Fig. no. 1)

Conversely, factors showing none or insignificant impact are subsoil and geological subsurface, relief curvature and distance from a water course. The factor of average temperature has the highest impact ratio; this implicitly includes also the factor of elevation. The next most important impacts are the factors of precipitation and topographic exposure which have more or less the same values of Wilk's lambda in all three locations, thus it cannot be defined which of them is more significant. In the third category of importance are factors of orientation, slope gradient and solar radiation, whose values of importance do not vary much, however, for modelling the vegetation zone they are unsubstitutable in the model.

Vegetation zones modelling was performed by using two different methods: MLC classification tools (maximum likelihood classification) and classification function of discriminant analysis. Both procedures resulted in creating a new raster depicting spatial distribution as an outcome of geospatial match of influential abiotic factors with OPRL typology as a training set. In the case of a large number of pixels there is a match in probability of classification into two different vegetation zones. These pixels are identified by double-digit values signifying transition between vegetation zones (concerning 18\% raster pixels at average).

The mutual concordance of newly created maps and the original typology of OPRL data in the location of the central Beskydy for MLC analysis is $91 \%$, at the classification function $80 \%$ (17\% pixels represents transitions between zones). In the Křtiny forest training region the concordance of output with the training set for MLC analysis is $73 \%$, at classification function $78 \%$ (26\% pixels represents transitions between zones). In the location of the Bílé Karpaty there occurred the concordance of the training set and the output for MLC analysis $83 \%$ at classification function $81 \%$ (11\% pixels represents transitions between zones). 
Table 3: Concordance of models with data of training set (OPRL)

\begin{tabular}{|c|c|c|c|}
\hline Study area & $\begin{array}{c}\text { Concordance of } \\
\text { MLC and OPRL }\end{array}$ & $\begin{array}{c}\text { Concordance of class. } \\
\text { function and OPRL }\end{array}$ & $\begin{array}{c}\text { Transitions between two } \\
\text { zones at the class. function }\end{array}$ \\
\hline Beskydy & $91 \%$ & $80 \%$ & $17 \%$ \\
\hline Bílé Karpaty & $83 \%$ & $81 \%$ & $11 \%$ \\
\hline ŠLP Křtiny & $73 \%$ & $78 \%$ & $26 \%$ \\
\hline
\end{tabular}

\section{DISCUSSION}

As expected in the analyzed model, vegetation zones are primarily affected by mean temperature and precipitation. The third significant factor, topographical exposure, is nevertheless nominally (by expressing Wilk's lambda value) equally influential as the above mentioned precipitation (see Fig. no. 1.) Topographical exposure, i.e. exposure of the locality towards surrounding landscape, is an abiotical factor that can primarilly reflect the inversion of vegetation zones; however, the procedure of creating a raster map of this particular factor employs contour lines which are available in the full extent of the study site, contrary to temperature and precipitation layers which are based on interpolation of values collected by several climatological stations and rain gauges. Local extremes of topographical exposure are thus expressed in more detail then with precipitation or temperature which are being generalized during the processing. This fact apparently leads to overestimation of the influence of topographic exposure on vegetation zonality at the expense of precipitation. This factor is, however, essential in analytical modelling of the studied phenomenon, as well as other factors with lower levels of significance, i.e. slope, exposition and solar radiation.

The source data for precipitation maping is missing an information on horizontal precipitation, which makes up a significant proportion of the total rainfall, especially in mountaneous areas. When incorporating these data into the model, local extremes would be probably highlighted which would increase the influence of this factor on studied phenomenon spatial distribution.

Mutual variability of the values determining the degree these factor influence the vegetation zonality at individual areas varies with distinct topographic characteristics and climate. Value of topographic exposure factor reaches higher level of influence at the central Beskydy Mountains than at the Bílé Karpaty Mountains, which corresponds with reality. This information however shows the necessarity of suitable selection of the study areas, which may have a high variability in presence of individual vegetation zones, but not a high variability of topographical and climatic characteristics. Analogously, an enlargement of studied area causes a generalization of the modelled phenomenon.

The climatical data used in the model date from the 1966 to 1990 , which means the data are out-of-date, but this has no significant effect on the model analysis, which primarilly considers their relative spatial variability and distribution and not their actual value. For the topographical characteristic, the contour data of ZABAGED were used. These are not continuous in locations of extreme terrain singularities (cliffs, ravines etc.) which are ommited in the resulting model. Only by field research it is possible to map the vegetation zonality on these sporadic sites.

Resulting rasters created by classification models have different degree of match to the vegetation zones from OPRL data in different areas. The difference in the outputs may be a result of a much more detailed typization of vegetation zones in the OPRL data compared 
with actual variability of the area, or due to different approach or subjective view of each surveyor. Due to the nature of the vegetation zone training sets (typhological OPRL maps based on the field mapping) it is necesarry to expect many errors in the input data which inevitably affect the modelling analyses output. The influence of local training data errors on analytic outputs can be considered insignificant when compared to the volume of input data and taking the random distribution of sporadic errors into account. On the contrary, the used analysis can identify these inconsistencies, which is going to be validated by a field survey.

\section{SUMMARY}

According to the discriminant analysis among the most significant factors affecting spatial distribution of vegetation zones are factors of temperature, precipitation, topographic exposure and solar radiation, orientation and slope gradient. Conversely, factors showing none or insignificant impact are subsoil and geological subsurface, relief curvature and distance from a water course. The factor of average temperature has highest impact ratio, this implicitly includes also the factor of elevation. The following most important impacts are the factors of precipitation and topographic exposure which have more or less the same values of Wilk's lambda in all three locations, thus it cannot be defined which of them is more significant. In the third category of importance are factors of orientation, slope gradient and solar radiation.

Both analytical procedures of modelling vegetation zones (MLC and classification function) not only change the original distribution of Forest vegetation zones from typological maps but define forest vegetation zones also outside forest stands areas. High match quality (70-90\%) of newly created raster data depicting vegetation zones distribution with training set data from OPRL typology suggests high accuracy of analytical outputs, that will subsequently be verified by field studies.

When comparing both modelling procedures, the MLC analysis offers a partly generalized output, while the classification function creates a more detailed model of vegetation zonation. The disadvantage of classification function is a much more complicated data processing procedure and a classification inability at insufficiently represented categories of vegetation zones. Classification function is also unable to work with categories which are in the model represented on a very low scale (for example 2 and 3 forest vegetation zones in the Beskydy location) for modelling these categories by means of the above described method it is necessary to extend the chosen location so that the representation of individual FVZ (LVS) in the training set was proportional. Therefore, for larger areas the MLC analysis seems to be more suitable, while the classification function is a more effective tool for modelling smaller territories with a high quality of input data. For reaching effective results, at both alternatives, especially the classification function, it is necessary to chose a sufficiently large territory so that the model proportionally consists of all modelled vegetation zones, or the method can also be applied for defining chosen zones. The general qualitative variable denouncing efficiency and likelihood of outputs is similarly as at most geographical information analysis the quality of inputs.

The practical application of both methods is especially in modelling vegetation zones outside forest stands, where standard methods based on terrain phytocoenological survey cannot be used, this means in exposed urban areas or areas where the representation of species had been changed significantly. As this is a complex analytical model, it can be used for the simulation of forest vegetation zones displacement due to change of any abiotic 
factor. At the estimated rise in the values of the temperature factor, the model is able to respond interactively, which allows the study of vegetation zone displacement based on analytical documents. This application shall be subjected to a complex research in the future. The study may also make phytocoenological mapping easier or add to it, from the point of view of easier orientation in the terrain or helping to identify vegetation transitions or completing maps in terrains which are difficult to access. Future benefit may also be in applying these methods in landscape planning at the creation (and revision) of terrain systems of ecological stability, in agriculture for evaluating features of locations for plant breeding or for regional planning and infrastructure development.

\section{ACKNOWLEDGEMENTS}

This paper is made possible by the support of the research project of the Ministry of Education and Physical Training MSM 6215648902 "Forest and wood - the support of functional integrated forest management and using wood as renewable raw material" of the

IGA LDF MENDELU project No. 22/2010 "Support of spatial decision making in forests threatened by abiotic factors" and project IGA LDF MENDELU No. 33/2010 "Evaluation of the impact of factors affecting spatial distribution of forest vegetation zones by means of geographical information analysis".

\section{REFERENCES}

Buček, A., Lacina, J. (2002). Geobiocenologie II, Brno, MZLU v Brně: 10 - 37 pp.

Buček, A., Vlčková, V. (2009). Scénář změn vegetační stupňovitosti na území České republiky: deset let poté. Ochrana prírody, sv. 64

Grulich, V., Petříček, V. \& Culek, M. (2005). Problémy se zařazováním náhradní přírodě blízké vegetace do vegetačních stupňů. In: Culek, M., et. al., Biogeografické členění České republiky. II. Díl, Praha: Agentura ochrany př́rody a krajiny ČR.

Grulich, V., Culek, M. (2005). Poznámky k vegetačním stupňům. In: Culek, M. et.al., Biogeografické členěni České republiky. II. Díl, Praha: Agentura ochrany př́rody a krajiny ČR.

Hadaš, P., Mikita, T. (2008). Vliv reliéfu na formování vlhkostních poměrů národní prírodní rezervace Děvín. [CD-ROM]. Bioklimatologické aspekty hodnocení procesů v krajině: 1-14.

Imhof, E. (2007). Cartographic Relief Presentation, ESRI Press, Kalifornia: 110 - 142.

Klimánek, M. (2006). Digitální modely terénu. Brno: Mendelova zemědělská a lesnická univerzita v Brně, $85 \mathrm{~s}$.

Klimánek, M. (2007). Přesnost digitálního modelu terénu a jeho využití v lesnictví. Acta Universitatis agriculturae et silviculturae Mendelianae Brunensis, sv. LV, č. 4: 137 - 144.

Kubíková, J., Škop, M. \& Kubásek, J. (2010). Vicerozměrné statistické metody v programu Statistica, Praha: StatSoft. 51-54 pp.

Kusbach, A. (2000). Určení LVS - základ typologického mapování. In: Viewegh, J., Seminár Problematika lesnické typologie II, 19-21, Kostelec nad Černými lesy: ČZU.

Lanquaye, C.O., Mitchell S.J. (2005). Portability of stand-level empirical windthrow risk models. For. Ecol. Manage. 216: 134 - 148. 
Li, Z., Zhu, Q. \& Gold, Ch. (2005). Digital terrain modeling - Principles and Methodology, CRC Press, Washington: 84 - 127

Mikita, T., Klimánek, M. (2010). Topographic exposure and its practical applications. Journal of Landscape Ekology. sv. 3, č. 1: 42 - 51.

Pike, R.J., Evans, I. \& Hengl, T. (2008). Geomorphometry: A Brief Guide. In: Hengl, T., Hannes, I., Reuter (Eds.), Geomorphometry - Concepts, Software, Applications, Series Developments in Soil Science. Elsevier: 3-33, vol. 33,

Randuška, R., Vorel, J. \& Plíva, K. (1986). Fytocenológia a lesnícka typológia. Príroda, Bratislava.

Ruel, J.C. (1995). Understanding windthrow. Silvicultural implications. Forestry Chronicle 71: 434-444.

Ruel, J.C., Mitchell, S.J. \& Dornier, M. (2002). A GIS based approach to map wind exposure for windthrow hazard rating. Northern Journal of Applied Forestry. vol. 19: 183187.

Scott, R.E., Mitchell, S.J. (2005). Empirical modelling of windthrow risk in partially harvested stands using tree, neighbourhood and stand attributes. For. Ecol. Manage. 218: $193-209$.

Volařík, D. (2010). Application of digital elevation model for mapping vegetation tiers, Journal of forest science, 56, (3): 112-120.

Yokohama, R., Shirasawa, M. \& Pike, R.J. (2002). Visualizing Topography by Openness: A New Application of Image Processing to Digital Elevation Models, Photogrammetric Engineering and Remote Sensing (68), No. 3: 257-266.

Zlatník, A. (1976). Lesnická fytocenologie. Státní zemědělské nakladatelství. Praha. 